\title{
Practices of Innovation in Mobile Computing Alliances
}

DOI:

$10.1057 / 9781137007742$

Link to publication record in Manchester Research Explorer

\section{Citation for published version (APA):}

Lew, Y. K., Sinkovics, R. R., Harris, S. (Ed.), \& Kuivalainen, O. (Ed.) (2012). Practices of Innovation in Mobile Computing Alliances. In Internaional Business: New Challenges, New Forms, New Practices (pp. 242-262). Palgrave Macmillan Ltd. https://doi.org/10.1057/9781137007742

\section{Published in:}

Internaional Business: New Challenges, New Forms, New Practices

\section{Citing this paper}

Please note that where the full-text provided on Manchester Research Explorer is the Author Accepted Manuscript or Proof version this may differ from the final Published version. If citing, it is advised that you check and use the publisher's definitive version.

\section{General rights}

Copyright and moral rights for the publications made accessible in the Research Explorer are retained by the authors and/or other copyright owners and it is a condition of accessing publications that users recognise and abide by the legal requirements associated with these rights.

\section{Takedown policy}

If you believe that this document breaches copyright please refer to the University of Manchester's Takedown Procedures [http://man.ac.uk/04Y6Bo] or contact uml.scholarlycommunications@manchester.ac.uk providing relevant details, so we can investigate your claim.

\section{OPEN ACCESS}




\section{Manchester Business School}

\section{Centre for Comparative and International Business Research (CIBER)}

\section{Paper Series}

Manchester Business School The University of Manchester

Booth Street West

Manchester M15 6PB, UK

http://www.mbs.ac.uk/ciber/

Manchester Business School CIBER

Centre for Comparative and International Business Research http://www.mbs.ac.uk/ciber/

These papers are produced by the MBS CIBER - Centre for Comparative and International Business Research and are to be circulated for discussion purposes only. Their contents should be considered to be preliminary. The papers are expected to be published in due course, in a revised form. All rights reserved. 


\title{
Practices of innovation in mobile computing alliances
}

\author{
Yong Kyu Lew • Rudolf R. Sinkovics
}

\section{This is a pre-print (non-publisher's document). Please cite the published article:}

Lew, Yong Kyu and Rudolf R. Sinkovics (2012), "Practices of innovation in mobile computing alliances," in International business - New challenges, new forms, new perspectives, Simon Harris, Olli Kuivalainen, and Veselina Stoyanova (Eds.). Houndmills, Basingstoke, U.K.: Palgrave MacMillan, 242-261 (ISBN: 9780230320987). Available: http://www.manchester.ac.uk/escholar/uk-ac-man-scw:155962

\section{Abstract and Key Results}

- Global technology alliances (GTAs) and innovation capabilities are the two main themes in this chapter. Drawing on innovation concepts and the resource-based view, this chapter explains how firms gain access to complementary resources, dispersed in the international realm, and incorporate these within their organizations through GTAs.

\section{Key Words}

Global technology alliances; capabilities; innovation; strategic alliances; resource externalization; resource internalization

\section{Authors}

Dr Yong Kyu Lew $(\varangle)$

Adjunct Postdoctoral Researcher

Centre for Comparative \& International Business Research (CIBER)

The University of Manchester, Manchester Business School

Booth Street West, Manchester M15 6PB, UK.

E-mail: yklew01@gmail.com

Prof Dr Rudolf R. Sinkovics

Professor of International Business

Centre for Comparative \& International Business Research (CIBER)

The University of Manchester, Manchester Business School

Booth Street West, Manchester M15 6PB, UK.

(e-mail: Rudolf.Sinkovics@manchester.ac.uk, Web:

http://www.personal.mbs.ac.uk/rsinkovics ) 


\section{This is a pre-print (non-publisher's document). Please cite the published article:}

Lew, Yong Kyu and Rudolf R. Sinkovics (2012), "Practices of innovation in mobile computing alliances," in International business - New challenges, new forms, new perspectives, Simon Harris, Olli Kuivalainen, and Veselina Stoyanova (Eds.). Houndmills, Basingstoke, U.K.: Palgrave MacMillan, 242-261 (ISBN: 9780230320987). Available: http://www.manchester.ac.uk/escholar/uk-ac-manscw: 155962

\section{Acknowledgements}

We are grateful to Olli Kuivalainen and Simon Harris for their thoughtful steering of this manuscript towards successful publication. A previous version of this manuscript was presented at the Academy of International Business - UK \& Ireland Chapter conference in Edinburgh, 2011. We gratefully acknowledge encouraging comments received from anonymous conference reviewers and interactions with colleagues from the Comparative and International Business Research Centre (CIBER) at Manchester Business School (http://www.mbs.ac.uk/ciber) which helped the progression of this paper. 


\title{
Practices of innovation in mobile computing alliances
}

\author{
Yong Kyu Lew and Rudolf R. Sinkovics
}

\section{Introduction}

Global technology alliances (GTAs) and innovation capabilities are the two main themes in this chapter. Drawing on innovation concepts and the resource-based view, this chapter explains how firms gain access to complementary resources, dispersed in the international realm, and incorporate these within their organizations through GTAs. This emergent form of international resource-seeking and network collaboration across borders can be seen as a new phenomenon in international business (IB) (Kogut and Zander 1992; Rugman and D'Cruz 2000; Yamin 2011). Innovation capabilities can be attained by combining a firm's technology resources with those of overseas alliance partners and thus progress towards enhancement of competitive advantage. From a theoretical aspect, we combine the resource-based view with innovation concepts and comprehensively examine the dynamics of resources and innovation at both a firm and a network level.

Foreignness provides firms with innovation-creating opportunities in terms of a wider range of resource availability and accessibility (Glaister and Buckley 1996; Kafouros et al. 2008; Kotabe, Srinivasan, and Aulakh 2002). However, due to bounded rationality and heterogeneity, firms cannot keep their entire set of resources in-house and at the same time capture all of the market opportunities available in global high-velocity environments (Johanson and Vahlne 2009; Ohmae 1989). From technology and market development perspectives, GTAs permit firms to explore and exploit technological partnership opportunities in order to develop and sustain their completive advantage (Eisenhardt and Schoonhoven 1996; Podolny 1994). Thus, firms utilize resources from external actors to 
increase their technological capabilities, thereby achieving product innovation and market competence (Danneels 2002; Hagedoorn 1993; Hill and Rothaermel 2003; Narula and Hagedoorn 1999; Osborn and Baughn 1990; Song et al. 2005; Stuart 2000).

There is a growing interest in the business activities of high-tech firms in upstream value chains; yet, little international business (IB) research has looked at GTAs and innovation. Despite the fact that a large amount of value is generated through the research and development (R\&D) activities of firms in the upstream value chain (Hamel and Prahalad 1991; Mudambi 2007), the majority of global strategic alliance studies to date have focused on downstream segments of the value chain (e.g. manufacturer-distributor relationships). Empirical GTA studies in the IB literature mostly focus on a macro-level unit of analysis, based on secondary data sources, thus failing to explain the firm-level innovation capabilities attributable to GTAs in specific industry contexts. This leads to the following questions: Are GTAs critical to the innovation capabilities of firms in high-tech industries? If so, how do firms create idiosyncratic innovation through GTAs? Accordingly, the aim of this chapter is to explain the innovation capabilities that can be gained through GTAs. It also aims to explore the validity of the conceptual arguments, by illustrating the use of GTAs in a specific high-tech market, from the perspective of a focal firm.

The remainder of the chapter is structured as follows. In the next section, we examine GTAs and resource complementarity in high-tech industries. After this, innovation landscapes and the resource-based view are reviewed from a theoretical perspective. Integrating these elements conceptually, we discuss innovation capabilities from the aspects of new product development and market development. The subsequent sections illustrate a software firm's innovation through GTAs in the mobile computing market, and the final section provides conclusions to the chapter. 


\section{GTAs in high-tech industries}

\section{The rationale for GTAs in high-tech industries}

As a firm cannot internalize all of the resources available in the market, technology alliances are a good strategic option for firms seeking specific technology resources. GTAs allow a firm to access required resources which do not exist in its own local market, thus enabling it to bring the acquired complementary external resources within its own boundaries (Doz 1988; Kotabe and Swan 1995; Mathews 2006). By forging non-equity based organizational arrangements, a firm can efficiently anchor its technological position in global high-tech markets (Cantwell and Narula 2001; Osborn and Baughn 1990). For this reason, there are a growing number of GTAs worldwide in high-tech industries (Hagedoorn and Narula 1996; Narula and Hagedoorn 1999). GTAs encompass governance structures, such as joint R\&D agreements, R\&D contracts, co-production or co-development contracts, technology licensing, and technology sharing (Narula and Hagedoorn 1999); generally, market-related alliances which are accompanied by GTAs can also be included in this list (Oxley and Sampson 2004; Swaminathan and Moorman 2009). In this respect, GTAs are not only oriented towards technology development (e.g. technology complementarities, a reduction in the innovation time span), but also market access, market expansion, and influencing market structures (Glaister and Buckley 1996; Hagedoorn 1993; Jaworski, Kohli, and Sahay 2000; Varadarajan and Cunningham 1995).

One result of internal and external $R \& D$ investment in high-tech industries is that a firm's absorptive capacity, upon which its resource allocation for innovation rests, is increased (Cohen and Levinthal 1990; Dyer and Singh 1998; Miozzo and Grimshaw 2005; Rothaermel and Deeds 2006). There is a propensity for firms in technology-intensive industries (e.g. software, computers, semiconductors, and pharmaceuticals) to spend more R\&D expenditure on sales (Cantwell and Fai 1999; Kafouros et al. 2008; Kotabe, Srinivasan, 
and Aulakh 2002; Osborn and Baughn 1990). As technology investment can be taken as a proxy for innovation (Ahuja and Katila 2001; Teece 1996), valuable technology resource acquisitions, through external linkages, guarantee a firm's innovation. Therefore, taking into account the notion that innovation equates to technological invention and market competence, it can be seen that GTAs contribute to a firm's innovation capability which gives it a competitive advantage (Chesbrough 2003; Cooper 2001; Danneels 2002; Teece 1996).

\section{GTAs and resource complementarity}

Firms ought to identify their core technologies and strategically obtain new external technology resources in order to gain a competitive advantage in high-velocity industry environments (Porter 2004; Prahalad and Hamel 1990). As GTAs deal with complex relationships between different legal entities, partnering firms should identify how much resource complementarity exists prior to entering GTAs and then develop resource exchange governance mechanisms in the GTA structures (Gulati and Singh 1998; McCutchen, Swamidass, and Teng 2008). Proper governance of the exchange of technology resources in GTAs is critical to generating mutually beneficial outcomes (Hoetker and Mellewigt 2009). Owing to knowledge tacitness (Inkpen 2000; Kogut and Zander 1993), the more high-tech and knowledge-intensive the industry, the more complex the technology knowledge transfers between the partnering firms are. A firm can benefit from valuable external resources that can help it to overcome technological difficulties and the risks involved in complex product development in high-tech industries (Mitchell and Singh 1996). Thus, whether potential partners are capable of complementing their own technological innovation is critically important (Shapiro and Varian 1999).

A firm, as a repository of knowledge, has unique technological capabilities which differentiate it from other firms (Kogut and Zander 1992). The firm can create technological opportunities and successfully implement new technologies when it appropriately adapts 
technology resources to environments (Leonard-Barton 1988). As such, resource complementarity between partnering firms leads to technology dependence on partners in that the focal firm makes an effort to appropriate complementary resources from its partners in order to attain competitive heterogeneity (Lambe, Spekman, and Hunt 2002; Richey, Daugherty, and Roath 2007). Thus, the presence of complementary resources is an important criterion for selecting partners, and technology alliances provide partnering firms with the resources they need to create value (Harrison et al. 2001; Hitt et al. 2000). From a focal firm's perspective on GTAs, how to obtain complementary resources from external actors and achieve innovation is of crucial importance. To elaborate on this, the following sections discuss the theoretical foundations of this chapter, integrating the resource-based view with innovation concepts.

\section{Innovation and resource-based view}

\section{Innovation landscapes}

There is a large volume of innovation literature, ranging from sociology and economics to management. This chapter limits the scope of the discussion to product innovation perspectives, whilst taking into account resource acquisition through GTAs (Eisenhardt and Martin 2000; Powell, Koput, and Smith-Doerr 1996; Srinivasan, Lilien, and Rangaswamy 2002). Teece (1996) defines innovation as a quest into the unknown that includes examining and exploring technological and market opportunities. Similarly, Chesbrough (2003) distinguishes innovation from invention, stating that innovation has market-orientation. By processing the development and application of new ideas, a firm is able to create a new product, process, or business model (Galbraith 1982). As such, product innovation is one of the key dimensions of innovation, as technology resources encourage firms to innovate new products (Cooper 2001; Goffin and Mitchell 2005). Exploration and 
exploitation, in relation to radical and incremental innovation, are frequently recurring topics in the literature (see e.g. Eisenhardt and Martin 2000; Hill and Rothaermel 2003; McGrath 2001; Rothaermel and Deeds 2004; Zahra, Ireland, and Hitt 2000). This group of studies refers to March's work $(1991,71)$ :

"Exploration includes things captured by terms such as search, variation, risk taking, experimentation, play, flexibility, discovery, innovation. Exploitation includes such things as refinement, choice, production, efficiency, selection, implementation, execution."

Recent product innovation studies show that a firm's innovation capability is related to its level of radical or incremental innovation attributes (see e.g. Atuahene-Gima 2005; Atuahene-Gima and Murray 2007; Yalcinkaya, Calantone, and Griffith 2007). This being the case, how can firms in high-tech industries successfully acquire and coordinate technology resources for product invention and then successful commercialize these combined resources? Technology management and innovation scholars seek an answer in the concept of open innovation (see e.g. Chesbrough 2003, 2007; Dahlander and Gann 2010; Laursen and Salter 2006; Lichtenthaler 2008).

The idea of open innovation is that a firm's innovation activities can go beyond its internal R\&D boundary in pursuit of open inbound (e.g. acquiring or sourcing resources) and outbound innovation (e.g. selling or revealing resources) (Chesbrough 2003; Dahlander and Gann 2010; Lichtenthaler 2005). In other words, the use of internal and external technology resources and paths to the market help a firm to develop new ideas and accomplish innovation. Taking open strategic initiatives, a firm can create and capture new value from the contributions of outside institutions, such as communities, partners, volunteers, and its own business ecosystem, thereby achieving innovation quickly and economically (Broughton 2010; Chesbrough 2007; Chesbrough and Appleyard 2007). The concept of open innovation 
fits well with recent new business phenomena in high-tech industries, such as open-source software and community-based web businesses. In this respect, GTAs allow greater access to complementary resources, thus offering appropriated relational rent and inbound spillover rent (Lavie 2006).

\section{Resource-based view}

According to the resource-based view, a firm's valuable, inimitable, rare, and nonsubstitutable (VIRN) resources contribute to its competitive advantage (Barney 1991; Dyer and Singh 1998; Oliver 1997). From a focal firm's perspective on GTAs, the resource-based view complements the concept of innovation, in that it fundamentally assumes resource ownership and the heterogeneity of the firm. A commonality in the resource based view literature is that salient resources enable a firm to sustain a competitive advantage through its intentional firm-specific investments and use of resources (Barney 1991; Barney and Clark 2007; Cockburn, Henderson, and Stern 2000; Ethiraj et al. 2005). Accordingly, a firm attains competitive heterogeneity by exchanging complementary technology knowledge with external firms (Cantwell and Narula 2001; Choi and Lee 1997). Resources acquired through exchange relationships, that is, GTAs, ought to inwardly contribute to a firm's capability to gain successful relationship outcomes and create a competitive advantage (Hitt et al. 2000; Oliver 1997; Powell, Koput, and Smith-Doerr 1996; Rothaermel and Deeds 2006). As such, explicit and tacit technological knowledge is embedded in resource exchange relationships (Grant and Baden-Fuller 2004; Kogut and Zander 1996; Nonaka and Takeuchi 1995). Tacit knowledge exists in firms in the form of rare and imperfectly-imitable resources embedded in the organizational routines (Makhija 2003; Verbeke 2003). In this regard, a firm seeks to obtain requisite complementary resources by forming relationships with external firms (Hitt et al. 2000; Lorange and Roos 1993). From the resource-based view, it is critical for a firm to identify the resources it needs in order to build up its innovation capabilities. Thus, the 
resource-based view can be effective in explaining GTAs as it regards a firm as a bundle of resources, made up of both skills and knowledge (Eisenhardt and Schoonhoven 1996; Madhok 2002).

\section{Integrating the resource-based view with the concept of innovation}

Following the innovation concept of technological invention leading to market commercialization, a two-by-two matrix has been developed and is presented in Table 1 . The matrix shows that the resource-based view can be encapsulated using innovation concepts. The horizontal line shows two different sources of technology resources that can be used for technology development: internal and external; the vertical axis represents levels of valuecapturing actors involved in the commercialization of technological developments, given the two groups of resources. The resource-based view explains cells A and B at the bottom of the matrix, as the view looks upon a firm as the owner of VIRN resources which give it heterogeneity and a competitive advantage. These cells allow for technology development through the use of internal and external resources and also for their value-capturing commercialization by an economic actor at the firm level. By following this logic, firstly, firms in cell A (closed innovation) create and capture innovation, based on internal R\&D; in the Chandlerian innovation system, the traditional hierarchy (a firm) would be an example (Hedlund and Rolander 1990; Kristensen 2010; Williamson 1971; 1979).

Secondly, external resources contribute to a firm's technology development and commercial success through resource exchange governance mechanisms between economic actors (Gulati and Singh 1998; Sinkovics et al. 2011). With respect to this, an organizational form of quasi-hierarchy or quasi-market (e.g. a joint venture, or non-equity based technology alliance) exemplifies cell B, inbound innovation. Thus, the bottom cells (A and B) illustrate resource internalization at the firm level. 
By employing the open innovation concept, the level at which value is gained can be further extended from the firm to the network (Chesbrough 2007; Henkel 2006; Johanson and Mattsson 1987). Herein, network is taken to mean a group of value-capturing economic actors outside a resource-contributing firm; for instance, a network could be a focal firm's partners or ecosystem, an unspecified constellation of firms, or a community.

Cell C is termed 'inside-out innovation' not only to highlight resource externalization, but also to distinguish the term from pecuniary outbound innovation in the literature (e.g. selling internal resources, or outsourcing). Good examples of inside-out innovation, are OpenJDK (free Java software), developed by Sun Microsystems, and Google's Android operating system. OpenJDK is freely available as a part of Linux operating systems, such as Debian and Ubuntu. Even multi-national enterprises (e.g. Motorola, Samsung, LG, Motorola, Huawei, and HTC) have recently begun to adopt Google's free Android platform as their operating system, thereby producing commercially successful Smartphones. These firms have saved on resource-acquisition costs as well as internal technology development time by using free OpenSource software (Stallman 1999). Google on the other hand, as a resource contributor, gains value by directing the numerous customers of such devices, through the Android platform, to its internet site.

Finally, cell D is termed 'open network innovation' because networks of actors can benefit from the technology developments contributed by networks of actors (e.g. volunteer communities or a business ecosystem). The well-known case of the Linux open source kernel, initiated and released by open communities, belongs to cell D. Interestingly, resource contributors to cell C, such as Sun Microsystems and Google, are also beneficiaries of open network innovation, as they use open resources in their products. Thus, the upper cells (C and D) indicate that value can be created through externalizing resources, capturing and commercializing them at the network level. This implies that high-tech firms adopt their 
innovation strategies selectively with regard to the level of openness they apply to innovation process. As this chapter deals with firm-level GTAs and innovation capabilities, we highlight phenomena that illustrate cell B in the case study sections.

Table 1: Integrative innovation matrix from resource and openness perspectives

Commercialization

\begin{tabular}{|c|c|c|c|}
\hline \multirow[b]{2}{*}{$\begin{array}{r}\text { Network } \\
\text { level }\end{array}$} & & & \multirow[b]{2}{*}{$\begin{array}{l}\text { Resource } \\
\text { externalization }\end{array}$} \\
\hline & $\begin{array}{c}\text { C. Inside-out innovation } \\
\text { (e.g. Open platform - Google Android } \\
\text { operating system) }\end{array}$ & $\begin{array}{c}\text { D. Open network innovation } \\
\text { (e.g. Open community - Linux open } \\
\text { source software) }\end{array}$ & \\
\hline \multirow[t]{2}{*}{$\begin{array}{l}\text { Firm } \\
\text { level }\end{array}$} & $\begin{array}{l}\text { A. Closed innovation } \\
\text { (e.g. Internal R\&D -hierarchy in } \\
\text { Chandlerian innovation system ) }\end{array}$ & $\begin{array}{l}\text { B. Inbound innovation } \\
\text { (e.g. Quasi-hierarchies - strategic } \\
\text { technology alliances ) }\end{array}$ & \multirow[t]{2}{*}{$\begin{array}{l}\text { Resource } \\
\text { internalization }\end{array}$} \\
\hline & Firm's internal resources & Resources external to the firm & \\
\hline
\end{tabular}

\section{GTAs and product innovation}

In the resource-based view, a firm can infuse new technology resources accessed through GTAs into its organizational structure through internal bonding mechanisms, in order to generate capabilities (Amit and Schoemaker 1993). Product innovation and strategic alliances are entwined with firms' capabilities in high-tech industries, in that external linkages such as GTAs feed situation-specific new knowledge into the firm's technological innovation (Eisenhardt and Martin 2000; Teece 1996). Thus, the more innovation-oriented firm is likely to cooperate with external actors regarding technology (Chesbrough 2003; Eisenhardt and Schoonhoven 1996). Reflecting cell B in Figure 1, a firm's technological capability is determined by how it leverages internally-existing and externally-fuelled resources (Chesbrough 2003; Luo 2000; Metcalfe and Boden 1992; Teece, Pisano, and Shuen 1997). A corollary of its improved technological capability is the ability to improve and refine existing products and/or explore unique new product developments (Atuahene-Gima 2005; Grant and Baden-Fuller 2004; March 1991). Nevertheless, technologically advanced 
and innovative products will be unable to permeate the market unless the firm is capable of commercializing its ideas and technologies (Chesbrough 2004; Day 1994; Gittelman and Kogut 2003; Lichtenthaler 2008). When it comes to product innovation, therefore, the firm must have market development capabilities to complement its new product development capabilities.

\section{An illustration: a software company's GTAs and innovation capability}

Based on the theoretical discussions above, the following sections explore how firms exchange complementary technology resources through GTAs and use these to augment their innovation capabilities, in the context of the mobile computing market. Based on interviews with senior managers and secondary sources of information, we will illustrate a GTA between a personal computer (PC) software firm in South Korea and its global hardware and software technology partners. Ranked second in the local software industry, the focal firm used to develop PC software applications and server operating systems in the local market. This single case study will show how the focal firm gains access to overseas complementary resources through GTAs, internalize the resources, develop technologically new products, and commercialize them in the new mobile computing market.

\section{GTAs in the mobile computing market}

Wireless technologies (e.g. 3G, Wi-Fi, Bluetooth) have triggered the formation and expansion of the mobile computing market (ABI Research 2008; Ansari and Garud 2009). Market growth has recently accelerated, due to advancements in central processing unit (CPU) technologies (e.g. low battery power consumption, high CPU performance) (ARM 2009; Intel 2009). The upstream value chain of the market consists of software and hardware firms, numerous component suppliers, and device manufacturers. Cross-industry cooperation between IT firms has contributed to some highly innovative and rapid product development 
(e.g. high-end smartphones, portable netbooks, and touchbooks). The latest products support mobile communication functionality, a high level of computing power, and internetsupported multimedia data streaming (ARM 2009; Intel 2009; Sharon and Eric 2009). Thirdparty applications are also embraced. There are growing numbers of GTAs between software (e.g. operating systems, application platforms, and application software) and hardware (e.g. chip design, microcontrollers, system-on-chips, and graphics/video) firms at the end of the upstream value chain, an example of which is shown in Figure 1 (Waters 2011). A firm's strategic decisions as to how it cooperates with other firms determine its success or failure in turbulent markets (Kale, Singh, and Perlumutter 2000; Shapiro and Varian 1999). External linkages allow firms in the upstream value chain to secure complementary technology resources and develop innovative products (Harrison et al. 2001; Jaworski, Kohli, and Sahay 2000; Kotabe and Swan 1995; Teece 1996). As such, technology alliances are an indispensible part of the strategies of software and hardware firms in the mobile computing market. It is unlikely, and certainly not current practice that IT firms would internalize all the technology resources available. As such, a brief case study in the following section illustrates how a software firm based in South Korea has generated innovation capabilities through its GTAs with heterogeneous foreign firms. For readers' better understanding of the context of this case, Figure 1 shows the geographical locations and value chain positions of the case firms; it also shows a simple architecture of the mobile computing device, split logically into their components. Firm ' $A$ ' is the focal firm and 'B', 'C', and 'D' are its GTA partners in the case study. 
Figure 1: Firms in the case study - product architecture and value chain

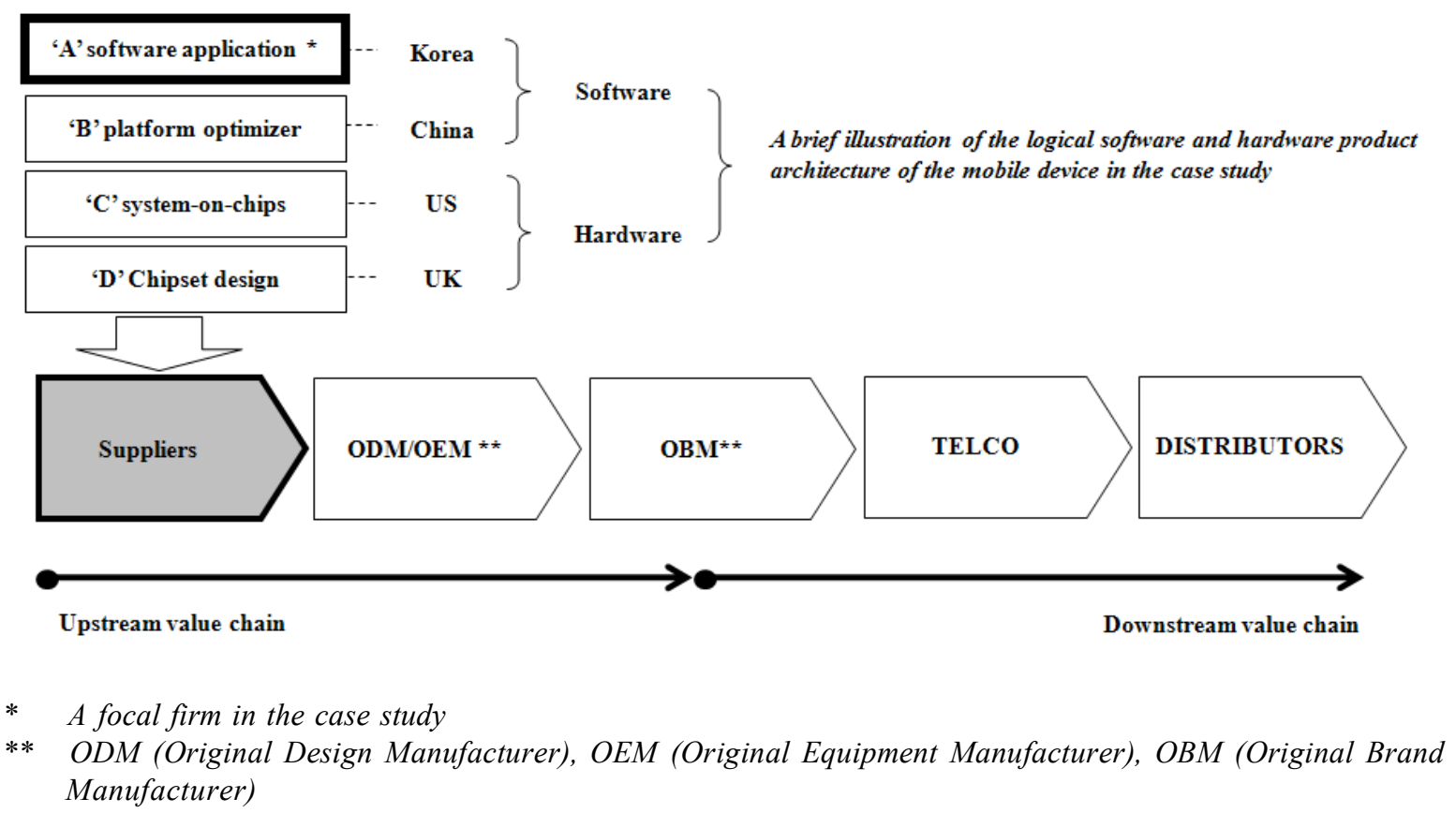

\section{Building a relationship through a GTA}

Originally, most of firm ' $A$ ' revenues were generated by PC package software distribution and licensing to companies, the government, and educational institutions. As the PC software market matured and became saturated, the focal firm ' $A$ ' invested in mobile software technology development and explored the market opportunities but was commercially unsuccessful until entering into a GTA with a hardware firm in the US. Firm ' $\mathrm{C}$ ' is a leading fabless semiconductor and telecommunication technology developer specializing in the design and sale of hardware devices and semiconductor chips while outsourcing the fabrication or 'fab' of the devices to a specialized manufacturer called a semiconductor foundry. Both firms ' $\mathrm{A}$ ' and ' $\mathrm{C}$ ' required resources from each other in order to develop new products and penetrate the growing mobile computing device market, worldwide. After a negotiation stage, contracts were drawn up and signed, laying down codevelopment and co-marketing agreements; the scope covered worldwide territories. The vice president of product management in firm ' $\mathrm{C}$ ' commented on this way of forming and managing strategic partnerships: 
"We see ourselves as system architect.... we identify the building blocks of the architecture. Then we identify partners that we want to work with on a building block. By building blocks and then we exchange appropriate information with these partners. We constantly re-define new technologies and new products and bring them successfully to market and they need commit the requirements of customers of the industries all the time, which means all the time we have to assess what are the partners really to work with; and what are the projects that we build with those partners.”

Firm 'C' required key software applications (e.g. communication, productivity, multimedia, entertainment) to develop feasible hardware architecture in order to commercialize its hardware product, chipsets. The director of product management in the software firm 'A' reflected on the GTA as follows:

"At that time, my company didn't monetize our technologies on the mobile platform (by partnering with ' $C$ '), our company management turned to pay attention to this area and allocated more engineering resources... our partner had been prepared for GHz CPU powered chipset for a long time and software partners was very important for them because they needed to show directly working software applications on their new high performance CPU to the market. They wanted to make a partnership with us to effectively develop software stacks on the top of their hardware platform."

The new mobile software product development environment was different from that of PC hardware, in which software firm ' $\mathrm{A}$ ' was used to working. Also, it was unable to obtain this new type of technology resources from its previous hardware partner in the local market. Thus, the GTA with hardware firm ' $\mathrm{C}$ ' allowed it to complement its own software technology resources with the new hardware resource, and integrate this new resource into its existing operations in order to develop new mobile software products. The vice president of the hardware firm pinpointed partnerships as one of the most critical factors behind successful new product developments: 
"First, a very good understanding of the status of the industry. Second, it is a very creative and innovative workforce with attitude toward driving new technologies, new products and new ideas that meet the needs of customers. And, third, an ability to build the relationships within the new industries in order to build a market. Without partnerships, we cannot build the market."

Through the GTA, firm 'A' was provided with the proprietary hardware platform resources and knowledge it needed for its software development, by hardware firm ' $\mathrm{C}$ '. The Chief Technology Officer of firm ' $A$ ' made the following comment about the resource exchange governance in the GTA:

"At the beginning, we shared development tasks through sorts of workshops and reviewed problems and tasks and discussed development milestones. They (firm ' $C$ ') continuously provided us with testable environments and engineering units. So, we easily managed project tasks.”

\section{Complementary resources for new product development}

Firm ' $A$ ' confronted technological difficulties in integrating its software prototype with the hardware platform from firm ' $\mathrm{C}$ ' during the new product development stage. In order to resolve this, firm ' $A$ ' needed technology resources in the form of low-level (kernel) system knowledge and the optimization of software with hardware. Thus, it entered into additional GTAs with firms ' $\mathrm{B}$ ' and ' $\mathrm{D}$ ' to tackle the technological problems it was encountering in its new product development with firm ' $\mathrm{C}$ '; ' $\mathrm{B}$ ' is an operating system development firm in China and ' $D$ ' a chipset design firm in the UK. Since both firms already had close relationships with firm ' $\mathrm{C}$ ', the focal software firm was able to extend its technology development relationships to include them quite smoothly. The director of firm 'A' discussed the difficulties of new product development, as shown below:

"Developing a new product is not a simple technical task. Many issues are interlinked so that the important point is to know what a problem is and how to solve the problem... There were problems originated from the code optimization of the 
hardware system and there were problems with hardware-runtime from operating system issues. During the product development process, we identified further development tasks and issues to resolve. Although the project was initiated by the chipset company (firm ' $C$ ') and software application provider (firm 'A'), other cooperative firms were also involved in the product and we resolved problems together. Without the other partners, we couldn't reach the project goals."

By sharing technology knowledge about kernel-level operating systems with firm 'B', firm 'A' was able to optimize its development of mobile application software using firm 'B's different types of kernel-level systems, including Android, on top of firm 'C's hardware architecture (see Figure 1). Subsequently, firm 'A' forged a partnership with firm ' $D$ ' by joining that firm's global software ecosystem, after being introduced by its initial hardware partner, 'C'. Firm 'D' was the original intellectual property (IP) designer of the core technologies used in the chipset of firm ' $C$ '. The GTA with firm ' $D$ ' provided firm ' $A$ ' with greater access to mobile hardware and software technologies (e.g. application platforms, power-saving, audio and graphic technologies). The GTA also enabled the focal firm to gain a better understanding of the whole technology architecture and dynamic market trends. Table 2 summarizes the series of GTAs from the aspect of the focal software firm. 
Table 2: Summary of GTAs between the focal firm and its network

\begin{tabular}{|c|c|c|c|}
\hline Perspectives & $\begin{array}{c}\text { GTA partner 'C' } \\
\text { (Fabless semiconductor) }\end{array}$ & $\begin{array}{c}\text { GTA partner 'B' } \\
\text { (Operating system developer) }\end{array}$ & $\begin{array}{l}\text { GTA partner 'D' } \\
\text { (Chipset IP designer) }\end{array}$ \\
\hline Key business & $\begin{array}{l}\text { - Licensing system-on- } \\
\text { chips to OxM* customers }\end{array}$ & $\begin{array}{l}\text { - Engineering service and } \\
\text { license solutions to OxM }\end{array}$ & $\begin{array}{l}\text { - Licensing designed } \\
\text { blueprints to semicon- } \\
\text { doctor/ OxM }\end{array}$ \\
\hline $\begin{array}{l}\text { Sequence, } \\
\text { relationships }\end{array}$ & (2007) & (2008) & $(2008)$ \\
\hline $\begin{array}{l}\text { Motivation from } \\
\text { partners' aspects }\end{array}$ & $\begin{array}{l}\text { - Develop new product } \\
\text { - Build a feasible product } \\
\text { architecture }\end{array}$ & $\begin{array}{l}\text { - Develop a software solution } \\
\text { - Build new business model }\end{array}$ & $\begin{array}{l}\text { - Build mobile software } \\
\text { ecosystem } \\
\text { - Expand its architecture } \\
\text { base }\end{array}$ \\
\hline \multicolumn{4}{|l|}{ Benefit to firm ' $A$ ' } \\
\hline Resource & $\begin{array}{l}\text { - Hardware development } \\
\text { resources and technical } \\
\text { support }\end{array}$ & $\begin{array}{l}\text { - Different types of optimized } \\
\text { operating systems }\end{array}$ & $\begin{array}{l}\text { - Prototype development } \\
\text { platform }\end{array}$ \\
\hline $\begin{array}{r}\text { New product } \\
\text { development } \\
\text { capability }\end{array}$ & $\begin{array}{l}\text { - Knowledge about mobile } \\
\text { development environments } \\
\text { - Hardware integration skills }\end{array}$ & $\begin{array}{l}\text { - Operating system integration } \\
\text { skills } \\
\text { - Kernel-level knowledge }\end{array}$ & $\begin{array}{l}\text { - Identify technology } \\
\text { development roadmap } \\
\text { - Hardware knowledge }\end{array}$ \\
\hline $\begin{array}{r}\text { Market } \\
\text { development } \\
\text { capability }\end{array}$ & $\begin{array}{l}\text { - Market sensing } \\
\text { - International marketing } \\
\text { - New market development }\end{array}$ & $\begin{array}{l}\text { - Customer development } \\
\text { - Understand Chinese market }\end{array}$ & $\begin{array}{l}\text { - Industry-wide market } \\
\text { trend and dynamics } \\
\text { - Customer creating and } \\
\text { linking opportunities }\end{array}$ \\
\hline Performance & $\begin{array}{l}\text { - Increased product launch } \\
\text { - Create new business } \\
\text { models both B2B and B2C } \\
\text { - Relational rent (access to } \\
\text { network resources of firm } \\
\text { 'B' and 'C') } \\
\text { - Increased global reputation }\end{array}$ & $\begin{array}{l}\text { - Include new products in } \\
\text { ready-to-use solution of firm } \\
\text { 'B' } \\
\text { - Increased customer base }\end{array}$ & $\begin{array}{l}\text { - Access to new software } \\
\text { and hardware resources } \\
\text { - Form new partnerships } \\
\text { in the joined ecosystem } \\
\text { - Increased global } \\
\text { reputation }\end{array}$ \\
\hline
\end{tabular}

*OxM: OEM, ODM, OBM

\section{Market development}

Besides the co-development that went on between firms ' $A$ ' and ' $C$ ', they also actively exchanged market development strategies and key market information and engaged in joint pre-marketing by demonstrating their prototype at key IT exhibitions worldwide. Furthermore, the business development teams of both firms carried out co-market development activities geared towards potential customers (e.g. ODM, OBM, and telecommunication firms), in order to quickly introduce their new software and hardware. One of our interviewees commented on the criticality of commercializing new innovative products, as follows: 
"The successful factor of a project is to develop a product that we can sell to the market... To develop a product that did not exist in the market, we had to develop a prototype and promote and expose this worldwide. For this, we invested a lot on engineering resources to develop marketable products."

As a result of the market development activities, the focal software firm was able to successfully launch three new mobile software products in 2009 , which were new to the market. The firm's new products were operationalized on top of firm 'C's hardware platform which used firm 'D's core technology. Also, the software firm created additional B2B and B2C business models, providing mobile software licenses to OxMs and App store distribution to end users. In addition, firm ' $\mathrm{A}$ ' was able to build relationships with other foreign software and hardware firms within the ecosystem of firm ' $\mathrm{D}$ ', thus increasing its product functionality and quality. The management of the software firm expected the new mobile products to account for ten per cent of annual revenues in 2010. Figure 2 encapsulates the illustrated case from the focal software firm's perspective. Its initial need for mobile hardware technology resources led to sequential GTAs with semiconductor, operating system, and chipset design firms. External resources gained through these relationships invigorated its technological and market development capabilities, giving it a competitive advantage.

\section{Figure 2: Relationships between resources, GTAs, and innovation capabilities in the case study}
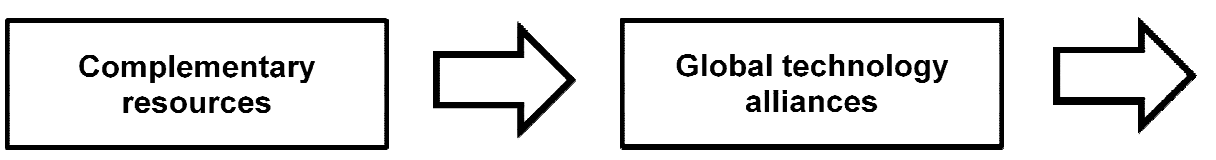

Innovation capabilities

\section{Conclusion}

In this chapter, we have investigated the interrelationships between complementary resources, GTAs, and innovation capabilities, in the context of the high-tech market. To do this, we have attempted to develop an integrative matrix encompassing the resource-based view and innovation concepts, thus typologizing closed, inbound, inside-out and open 
network innovation. This approach allows external actors to contribute resources to the technological value of a firm and allows the firm to gain commercial value-capturing rent from the resource-based view and innovation aspects (Chesbrough and Appleyard 2007; Lavie 2006). Particularly, we have focused on the inbound innovation, cell B in Table 1, in order to explain the contribution of external resources from international partners on a firmlevel product innovation. As such, we have further explored the conceptual discussion by illustrating how an idiosyncratic firm created innovation capabilities through GTAs in the mobile computing market. This allowed us to identify a sequence of relationships between three dimensions: resources, relationships, and capabilities. Firstly, the resource complementarity of firms inspires them to forge GTAs in high-tech industries; secondly, these GTAs help to increase firms' innovation capabilities.

This work contributes to the IB field on both a theoretical and an empirical level. Firstly, a theoretically-integrated matrix, in terms of the resource-based view and innovation, allows for a dynamic perspective, capturing resource internalization and externalization and encompassing the notion of open innovation. This also explains how GTAs contribute to firm-level product innovation and commercialization. Secondly, this chapter extends the extant IB literature that has primarily focused on interfirm relationships in the downstream value chain, from a marketing perspective, to the upstream value chain, looking at the context of technology. Thirdly, the illustrated case shows how GTAs allow a firm to acquire valuecreating complementary resources which are not available and accessible in the local market, thereby creating new business models and penetrating a new market. Thus, company managers engaged in international business activities should be aware that internationalization of a firm in the innovation process can play a critical role in strengthening and reinforcing innovation capabilities in high-tech industries. Also, managers in $\mathrm{R} \& \mathrm{D}$ or product management functions should understand the criticality of value- 
capturing market development capability as well as technological product development capability in product innovation.

Finally, the conceptual matrix and explorative case study in this chapter provide a basis for empirical research. An empirically-tested model would be able to explain to what extent complementary resources, obtained through resource bonding mechanisms in GTAs, contribute to the capability to create a competitive advantage through innovation. Although we have endeavoured to provide a rich description of the relationships between the focal firm and its GTA partners, it is difficult to generalize our findings based on this single case. It may be applicable and limited to explaining phenomena in the mobile computing market. In this respect, a large-scale primary survey would be a useful area of future research. We would recommend including the openness construct, and using the context of high-tech industries, which have rarely been investigated in the IB literature. This would enrich the limited discussions provided in this chapter and allow for the capture of dynamic bona fide GTA and innovation phenomena.

\section{References}

ABI Research (2008), "Mobile Internet Device," in. Oyster Bay: ABI Research.

Ahuja, Gautam and Riitta Katila (2001), "Technological Acquisitions and the Innovation Performance of Acquiring Firms: A Iongitudinal Study," Strategic Management Journal, 22 (3), 197-220.

Amit, Raphael and Paul J H Schoemaker (1993), "Strategic Assets and Organizational Rent," Strategic Management Journal, 14 (1), 33-46.

Ansari, Shahzad and Raghu Garud (2009), "Inter-Generational Transitions in SocioTechnical Systems: The Case of Mobile Communications," Research Policy, 38 (2), 382-392.

ARM (2009), "Enabling Innovation Creating Value: Annual Review 2008," in. Cambridge: ARM.

Atuahene-Gima, Kwaku (2005), "Resolving the Capability - Rigidity Paradox in New Product Innovation," Journal of Marketing, 69 (4), 61-83.

Atuahene-Gima, Kwaku and Janet Y. Murray (2007), "Exploratory and Exploitative Learning in New Product Development: A Social Capital Perspective on New Technology Ventures in China," Journal of International Marketing, 15 (2), 1-29. 
Barney, Jay (1991), "Firm Resources and Sustained Competitive Advantage," Journal of Management, 17 (1), 99-120.

Barney, Jay B and Delwyne N Clark (2007), Resource-Based Theory (1st ed.). Oxford: Oxford University Press.

Broughton, Philip Delves (2010, 18 November 2010), "Another Way to Develop Idea," Financial Times, London, 16.

Cantwell, John and Felicia Fai (1999), "Firms as the Source of Innovation and Growth: The Evolution of Technological Competence," Journal of Evolutionary Economics, 9 (3), 331-366.

Cantwell, John and Rajneesh Narula (2001), "The Eclectic Paradigm in the Global Economy," International Journal of Economics of Business, 8 (2), 155-172.

Chesbrough, Henry W (2003), Open Innovation (1st ed.). Boston: Harvard Business School Press.

Chesbrough, Henry W (2004), "Managing Open Innovation," Research Technology Management, 47 (1), 23-26.

Chesbrough, Henry W (2007), "Why Companies Should Have Open Business Models," MIT Sloan Management Review, 48 (2), 22-28.

Chesbrough, Henry W. and Melissa M. Appleyard (2007), "Open Innovation and Strategy," California Management Review, 50 (1), 57-76.

Choi, Chong Ju and Soo Hee Lee (1997), "A Knowledge-Based View of Cooperative Relationships," in Cooperative Strategies, Paul W Beamish and J Peter Killing (Eds.). San Francisco: The New Lexington Press, 33-54.

Cockburn, Iain M., Rebecca M. Henderson, and Scott Stern (2000), "Untangling the Origins of Competitive Advantage," Strategic Management Journal, 21 (10-11), 1123-1145.

Cohen, Weseley M and Daniel A Levinthal (1990), "Absorptive Capacity: A New Perspective on Learning and Innovation," Administrative Science Quarterly, 35 (1), 125-152.

Cooper, Robert G (2001), Winning at New Products (3rd ed.). New York: Basic Books.

Dahlander, Linus and David M. Gann (2010), "How Open Is Innovation?," Research Policy, 39 (6), 699-709.

Danneels, Erwin (2002), "The Dynamics of Product Innovation and Firm Competences," Strategic Management Journal, 23 (12), 1095-1121.

Day, George S. (1994), "The Capabilities of Market-Driven Organizations," Journal of Marketing, 58 (4), 37.

Doz, Yves L (1988), "Technology Partnerships between Larger and Smaller Firms: Some Critical Issues," in Cooperative Strategies in International Business, Farok J Contractor and Lorange Peter (Eds.). 1st ed. Lexington: Lexington Books, 317-338.

Dyer, Jeffrey H and Harbir Singh (1998), "The Relation View: Cooperative Strategy and Sources of International Competitive Advantage," Academy of Management Review, 23 (4), 660-679.

Eisenhardt, Kathleen M and Jeffrey A Martin (2000), "Dynamic Capabilities: What Are They? ," Strategic Management Journal, 21 (10/11), 1105-1121

Eisenhardt, Kathleen M. and Claudia Bird Schoonhoven (1996), "Resource-Based View of Strategic Alliance Formation: Strategic and Social Effects in Entrepreneurial Firms," Organization Science, 7 (2), 136-150.

Ethiraj, Sendil K , Prashant Kale, M S Krishnan, and Jitendra V Singh (2005), "Where Do Capabilities Come from and How Do They Matter? A Study in the Software Services Industry," Strategic Management Journal, 26 (1), 25-45.

Galbraith, Jay R (1982), "Designing the Innovating Organization," Organizational Dynamics, $10(3), 4-25$. 
Gittelman, Michelle and Bruce Kogut (2003), "Does Good Science Lead to Valuable Knowledge? Biotechnology Firms and the Evolutionary Logic of Citation Patterns," Management Science, 49 (4), 366-382.

Glaister, Keith W and Peter J Buckley (1996), "Strategic Motives for International Alliance Formation," Journal of Management Studies, 33 (3), 301-332.

Goffin, Keith and Rick Mitchell (2005), Innovation Management (1st ed.). New York: Palgrave Macmillan.

Grant, Robert M and Charles Baden-Fuller (2004), "A Knowledge Accessing Theory of Strategic Alliances," Journal of Management Studies, 41 (1), 61-84.

Gulati, Ranjay and Harbir Singh (1998), "The Architecture of Cooperation: Managing Coordination Costs and Appropriation Concerns in Strategic Alliances," Administrative Science Quarterly, 43, 781-814.

Hagedoorn, John (1993), "Understanding the Rationale of Strategic Technology Partnering: International Mode of Cooperation and Sectoral Differences," Strategic Management Journal, 14 (5), 371-385.

Hagedoorn, John and Rajneesh Narula (1996), "Choosing Organizational Modes of Strategic Technology Partnering: International and Sectoral Differences," Journal of International Business Studies, 27 (2), 265-284.

Hamel, Gary and C K Prahalad (1991), "Corporate Imagination and Expeditionary Marketing," Harvard Business Review, 69 (4), 81-92.

Harrison, Jeffrey S, Michael A Hitt, Robert E Hoskisson, and R Duane Ireland (2001), "Resource Complementarity in Business Combinations: Extending the Logic to Organizational Alliances," Journal of Management, 27, 679-690.

Hedlund, Gunnar and Dag Rolander (1990), "Actions in Heterarchies: New Approaches to Managing MNC," in Managing the Global Firm, Christopher A Bartlett, Yves Doz, and Gunnar Hedlund (Eds.). 1st ed. New York: Routledge, 15-46.

Henkel, Joachim (2006), "Selective Revealing in Open Innovation Processes: The Case of Embedded Linux," Research Policy, 35 (7), 953-969.

Hill, Charles W. L. and Frank T. Rothaermel (2003), "The Performance of Incumbent Firms in the Face of Radical Technological Innovation," Academy of Management Review, $28(2), 257-274$.

Hitt, Michael A., M. Tina Dacin, Edward Levitas, Jean-Luc Arregle, and Anca Borza (2000), "Partner Selection in Emerging and Developed Market Contexts: Resource-Based and Organizational Learning Perspectives," Academy of Management Journal, 43 (3), 449-467.

Hoetker, Glenn and Thomas Mellewigt (2009), "Choice and Performance of Governance Mechanisms: Matching Alliance Governance to Asset Type," Strategic Management Journal, 30 (10), 1025-1044.

Inkpen, Andrew C. (2000), "Learning through Joint Ventures: A Framework of Knowledge Acquisition," Journal of Management Studies, 37 (7), 1019-1043.

Intel (2009), "Mobility's Next Wave of Growth." Sunnyvale: Intel Corp.

Jaworski, Bernard, Ajay K. Kohli, and Arvind Sahay (2000), "Market-Driven Versus Driving Markets," Journal of the Academy of Marketing Science, 28 (1), 45-54.

Johanson, Jan and Jan-Erik Vahlne (2009), "The Uppsala Internationalization Process Model Revisited: From Liability of Foreignness to Liability of Outsidership," Journal of International Business Studies, 40 (9), 1411-1431.

Johanson, Jan and Lars-Gunnar Mattsson (1987), "Interorganizational Relations in Industrial Systems: A Network Approach Compared with the Transaction-Cost Approach," International Studies of Management \& Organization, 17 (1), 34-48. 
Kafouros, Mario I., Peter J. Buckley, John A. Sharp, and Chengqi Wang (2008), "The Role of Internationalization in Explaining Innovation Performance," Technovation, 28 (1-2), 63-74.

Kale, Prashant, Harbir Singh, and Howard Perlumutter (2000), "Learning and Protection of Proprietary Assets in Strategic Alliances: Building Relational Capital," Strategic Management Journal, 21 (3), 217-237.

Kogut, Bruce and Udo Zander (1992), "Knowledge of the Firm, Combinative Capabilities, and the Replication of Technology," Organization Science, 3 (3), 383-397.

Kogut, Bruce and Udo Zander (1993), "Knowledge of the Firm and the Evolutionary Theory of the Multinational Corporation," Journal of International Business Studies, 24 (4), 625-645.

Kogut, Bruce and Udo Zander (1996), "What Firms Do? Coordination, Identity, and Learning," Organization Science, 7 (5), 502-518.

Kotabe, Masaaki, Srini S Srinivasan, and Preet S Aulakh (2002), "Multinationality and Firm Performance: The Moderating Role of R\&D and Marketing Capabilities," Journal of International Business Studies, 33 (1), 79-97.

Kotabe, Masaaki and K Scott Swan (1995), "The Role of Strategic Alliances in HighTechnology New Product Development," Strategic Management Journal, 16 (8), 621636.

Kristensen, Hull Peer (2010), "Transformative Dynamics of Innovation and Industry: New Roles for Employees?," Transfer: European Review of Labour and Research, 16 (2), 171-183.

Lambe, C. Jay, Robert E. Spekman, and Shelby D. Hunt (2002), "Alliance Competence, Resources, and Alliance Success: Conceptualization, Measurement, and Initial Test," Journal of the Academy of Marketing Science, 30 (2), 141-158.

Laursen, Keld and Ammon Salter (2006), "Open for Innovation: The Role of Openness in Explaining Innovation Performance among U.K. Manufacturing Firms," Strategic Management Journal, 27 (2), 131-150.

Lavie, Dovev (2006), "The Competitive Advantage of Interconnected Firms: An Extension of the Resource-Based View," Academy of Management Review, 31 (3), 638-658.

Leonard-Barton, Dororthy (1988), "Implementation as Mutual Adaptation of Technology and Organization," Research Policy, 17 (5), 251-267.

Lichtenthaler, Eckhard (2005), "Corporate Diversification: Identifying New Businesses Systematically in the Diversified Firm," Technovation, 25 (7), 697-709.

Lichtenthaler, Ulrich (2008), "Integrated Roadmaps for Open Innovation," Research Technology Management, 51 (3), 45-49.

Lorange, Peter and Johan Roos (1993), Strategic Alliances (1st ed.). Cambridge: Blackwell.

Luo, Yadong (2000), "Dynamic Capabilities in International Expansion," Journal of World Business, 35 (4), 355-378.

Madhok, Anoop (2002), "Reassessing the Fundamentals and Beyond: Ronald Coase, the Transaction Cost and Resource-Based Theories of the Firm and the Institutional Structure of Production," Strategic Management Journal, 23, 535-550.

Makhija, Mona (2003), "Comparing the Resource-Based and Market-Based Views of the Firm: Empirical Evidence from Czech Privitation," Strategic Management Journal, 24, 433-451.

March, James G. (1991), "Exploration and Exploitation in Organizational Learning," Organization Science, 2 (1), 71-87.

Mathews, John (2006), "Dragon Multinationals: New Players in 21 Century Globalization," Asia Pacific Journal of Management, 23 (1), 5-27. 
McCutchen, Jr William W, Paul M Swamidass, and Bing-Sheng Teng (2008), "Strategic Alliance Termination and Performance: The Role of Task Complexity, Nationality, and Experience," The Journal of High Technology Management Research, 18 (2), 191-202.

McGrath, Rita Gunther (2001), "Exploratory Learning, Innovative Capacity, and Managerial Oversight," Academy of Management Journal, 44 (1), 118-131.

Metcalfe, Stan and Mark Boden (1992), "Evolutionary Epistemology and the Nature of Technology Strategy," in Technological Change and Company Strategies, Joseph Coombs, Paolo Saviotti, and Vivien Walsh (Eds.). London: Academic Press, 49-71.

Miozzo, Marcela and Damian Grimshaw (2005), "Modularity and Innovation in KnowledgeIntensive Business Services: It Outsourcing in Germany and the UK," Research Policy, 34 (9), 1419-1439.

Mitchell, Will and Kulwant Singh (1996), "Survival of Businesses Using Collaborative Relationships to Commercialize Complex Goods " Strategic Management Journal, 17 (3), 169-195

Mudambi, Ram (2007), "Offshoring: Economic Geography and the Multinational Firm," Journal of International Business Studies, 38 (1), 206.

Narula, Rajneesh and John Hagedoorn (1999), "Innovating through Strategic Alliances: Moving Towards International Partnerships and Contractual Agreements," Technovation, 19 (5), 283-294.

Nonaka, Ikujiro and Hirotaka Takeuchi (1995), The Knowledge-Creating Company (1st ed.). New York: Oxford University Press.

Ohmae, Kenichi (1989), "The Global Logic of Strategic Alliances," Harvard Business Review, 67 (2), 143-154.

Oliver, Christine (1997), "Sustainable Competitive Advantage: Combining Institutional and Resource-Based Views," Strategic Management Journal, 18 (9), 697-713.

Osborn, Richard N and C. Christopher Baughn (1990), "Forms of Interorganizational Governance for Multinational Alliances " Academy of Management Journal, 33 (3), 503-519.

Oxley, Joanne E and Rachelle C Sampson (2004), "The Scope and Governance of International R\&D Alliances," Strategic Management Journal, 25 (8/9), 723-749.

Podolny, Joel M (1994), "Market Uncertainty and the Social Character of Economic Exchange," Administrative Science Quarterly, 39 (3), 458-483.

Porter, Michael E (2004), Competitive Advantage. New York: Free Press.

Powell, Walter W., Kenneth W. Koput, and Laurel Smith-Doerr (1996), "Interorganizational Collaboration and the Locus of Innovation: Networks of Learning in Biotechnology," Administrative Science Quarterly, 41 (1), 116-145.

Prahalad, C. K. and Gary Hamel (1990), "The Core Competence of the Corporation," Harvard Business Review, 68 (3), 79-91.

Richey, R. Glenn, Patricia J Daugherty, and Anthony S Roath (2007), "Firm Technological Readiness and Complementarity: Capabilities Impacting Logistics Service Competency and Performance," Journal of Business Logistics, 28 (1), 195-228.

Rothaermel, Frank T and David L Deeds (2006), "Alliance Type, Alliance Experience and Alliance Management Capability in High-Technology Ventures," Journal of Business Venturing, 21 (4), 429-460.

Rothaermel, Frank T. and David L. Deeds (2004), "Exploration and Exploitation Alliances in Biotechnology: A System of New Product Development," Strategic Management Journal, 25 (3), 201-221.

Rugman, Alan M and Joseph R D'Cruz (2000), Multinationals as Flagship Firms: Regional Business Networks. Oxford: Oxford University Press. 
Shapiro, Carl and Hal R Varian (1999), Information Rule. Boston: Harvard Business School Press.

Sharon, P. Hall and Anderson Eric (2009), "Operating Systems for Mobile Computing," Journal of Computing Sciences in Colleges, 25 (2), 64-71.

Sinkovics, Rudolf R., Ruey-Jer Jean, Anthony S. Roath, and S. Tamer Cavusgil (2011), "Does It Integration Really Enhance Supplier Responsiveness in Global Supply Chains?," Management International Review, 51 (2), 193-212.

Song, Michael , Cornelia Droge, Sangphet Hanvanich, and Roger Calantone (2005), "Marketing and Technology Resource Complementarity: An Analysis of Their Interaction Effect in Two Environmental Contexts," Strategic Management Journal, 26 (3), 259-276.

Srinivasan, Raji, Gary L Lilien, and Arvind Rangaswamy (2002), "Technological Opportunism and Radical Technology Adoption: An Application to E-Business," Journal of Marketing, 66 (3), 47-60.

Stallman, Richard M. (1999), "The Gnu Operating System and the Free Software Movement," in Open Sources: Voices from the Open Source Revolution, Chris DiBona, Sam Ockman, and Mark Stone (Eds.). Sebastopol, CA: O'Reilly, 53-70.

Stuart, Toby E (2000), "Internationalization Alliance and the Performance of Firms: A Study of Growth and Innovation Rates in a High-Technology Industry," Strategic Management Journal, 21 (8), 791-811.

Swaminathan, Vanitha and Christine Moorman (2009), "Marketing Alliance, Firm Networks, and Firm Value Creation," Journal of Marketing, 73 (5), 52-69.

Teece, David J (1996), "Firm Organization, Industrial Structure, and Technological Innovation," Journal of Economic Behavior \& Organization, 31 (6), 193-224.

Teece, David J, Gary P Pisano, and Amy Shuen (1997), "Dynamic Capability and Strategic Management," Strategic Management Journal, 18 (7), 509-533.

Varadarajan, P. Rajan and Margaret H. Cunningham (1995), "Strategic Alliances: A Synthesis of Conceptual Foundations," Journal of the Academy of Marketing Science, 23 (4), 282-296.

Verbeke, A (2003), "The Evolution View of the MNE and the Future of Internationalization Theory," Journal of International Business Studies, 36 (6), 498-504.

Waters, Richard (2011), "Microsoft Needs to Rethink Tablets," Financial Times, London

Williamson, Oliver E (1979), "Transaction-Cost Economics: The Governance of Contractual Relations," Journal of Law and Economics, 22 (2), 233-261.

Williamson, Oliver E. (1971), "The Vertical Integration of Production: Market Failure Considerations," The American Economic Review, 61 (2), 112-123.

Yalcinkaya, Goksel, Roger J. Calantone, and David A. Griffith (2007), "An Examination of Exploration and Exploitation Capabilities: Implications for Product Innovation and Market Performance," Journal of International Marketing, 15 (4), 63-93.

Yamin, Mohammad (2011), "A Commentary on Peter Buckley's Writings on the Global Factory," Management International Review, 51 (2), 285-293.

Zahra, Shaker A, R. Duane Ireland, and Michael A Hitt (2000), "International Expansion by New Venture Firms: International Diversity, Mode of Market Entry, Technological Learning, and Performance," Academy of Management Journal, 43 (5), 925-950. 